\title{
温熱・化学療法を同時に実現するスマートナノファイバーの開発 〜貼るがん治療を目指して〜
}

\author{
物質・材料研究機構 国際ナノアーキテクトニクス研究拠点 ${ }^{* 11}$. 筑波大学大学院 数理物質科学研究科 ${ }^{* 2}$ \\ - 東京理科大学大学院 基礎工学専攻 ${ }^{* 3)}$. Department of Bioengineering, University of Washington*4)
}

\section{新山瑛理 ${ }^{* 1,2)} \cdot$ 荏原充宏*1,2,3,4)}

\section{Smart Nanofiber Meshes for Cancer Thermo/Chemotherapy}

Polymeric nanofibers are an exciting new class of material and have attracted great attention because of their remarkable properties, such as high specific surface area, high porosity, high molecular alignment, or nanosize effects. Additionally, many different types of molecules can be easily incorporated into nanofibers to greatly expand their drug loading capacity or to provide the sustained release of the embedded drug molecules. Also, they can be easily manipulated as a macroscopic bulk matter that may create opportunities for profitable new uses as an implantable local drug delivery platform. This review article introduces four types of nanofibers; nanofibers with sustained and on-off drug release properties combined with thermo-therapy.

DDS と聞くと內科的治療が想像されがちだが、外科領域でもDDS の需要が多く聞かれる。がん 治療においても、約7割が外科手術との併用療法といわれている。本稿では、外科手術の後あるいは 併用して利用可能な DDS 基材について紹介する。特に、患部局所で薬物濃度を制御可能なナノファ イバーメッシュについて紹介する。ナノファイバーメッシュは、薬物の種類によらず作製可能なばか りか、無機物とのコンポジットも容易なため、温熱療法可能な磁性ナノ粒子内包メッシュの作製も可 能であり、その応用範囲の広がりには目を見張るものがある。

Eri Niiyama*1,2), Mitsuhiro Ebara*1,2,3,4)

Keywords: Nanofibers, smart polymers, electrospinning

\section{1.はじめに}

「さあーさあーお立会い」で始まる筑波山名物のガ マの油売りの口上。もともとは、大坂の陣に徳川方 として従軍した筑波山・中禅寺の住職が持参した陣 中薬に由来するといわれているが、このように塗っ たり貼ったりするだけで怪我や病気が治れば患者に とっては非常にありがたい。実際に軟膏タイプの抗 がん剂も使用されているが、薬物投与量の厳密な調 節が困難なことや、ふき取った後のガーゼの取り扱

\footnotetext{
${ }^{* 1)}$ International Center for Materials Nanoarchitectonics,

National Institute for Materials Science

${ }^{* 2)}$ Graduate School of Pure and Applied Sciences,

University of Tsukuba

${ }^{* 3)}$ Graduate School of Industrial Science and Technology,

Tokyo University of Science

${ }^{* 4)}$ Department of Bioengineering, University of Washington
}

いや処理を考えなければいけないなど、その利用は 限られている。こうした背景のもと、局所に貼るこ とが可能なシート型の薬物放出基材がにわかに注目 を集めている。特にその中でも、ウェアラブルの難 敵であるむれやかぶれを回避可能な通気性が高い メッシュ形状への注目は特に高い1)。メッシュ素材 は通気性だけでなく、大きな表面積や高いフレキシ ビリティーからも使い勝手がよく、特に外科医から 好まれている。実際にがん治療においても、外科的 治療の割合は化学療法や放射線療法との併用を含 めると、実に7割以上といわれており、外科的処置 と同時に利用可能な移植型局所 DDS 基材の開発は、 ある意味必然的な時流といえる(図1)。ナノファイ バーメッシュの作製法にはいくつかあるが、その中 でも電界紡糸法(エレクトロスピニング法)は、さま ざまな点においてメリットがあることからよく使 
がん患者が今までに受けた治療法*1

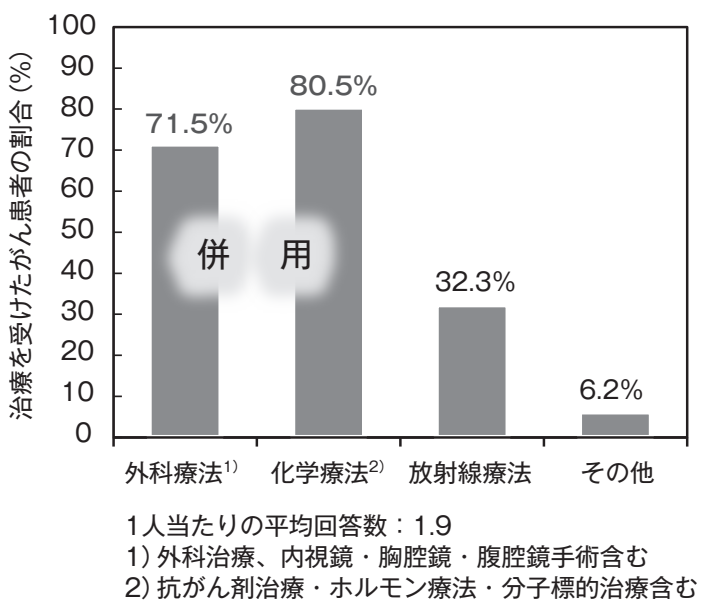

移植型局所DDS基材

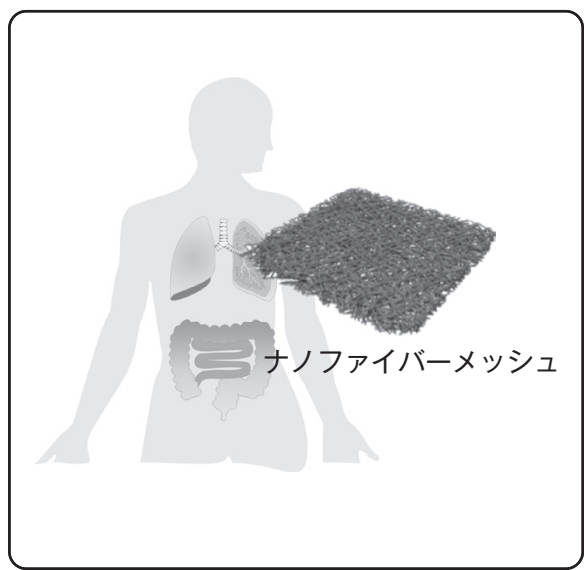

図1 がん患者が今まで受けた治療法の統計と、局所DDS を目指したナノファイバーメッシュの概念図

* 1 厚生労働省委託事業 平成 22 年度 がん対策評価・分析事業対象 : 377 施設のがん診療連携拠点病院に拈ける患者あるいは家族計 2,273 件(複数回答)。

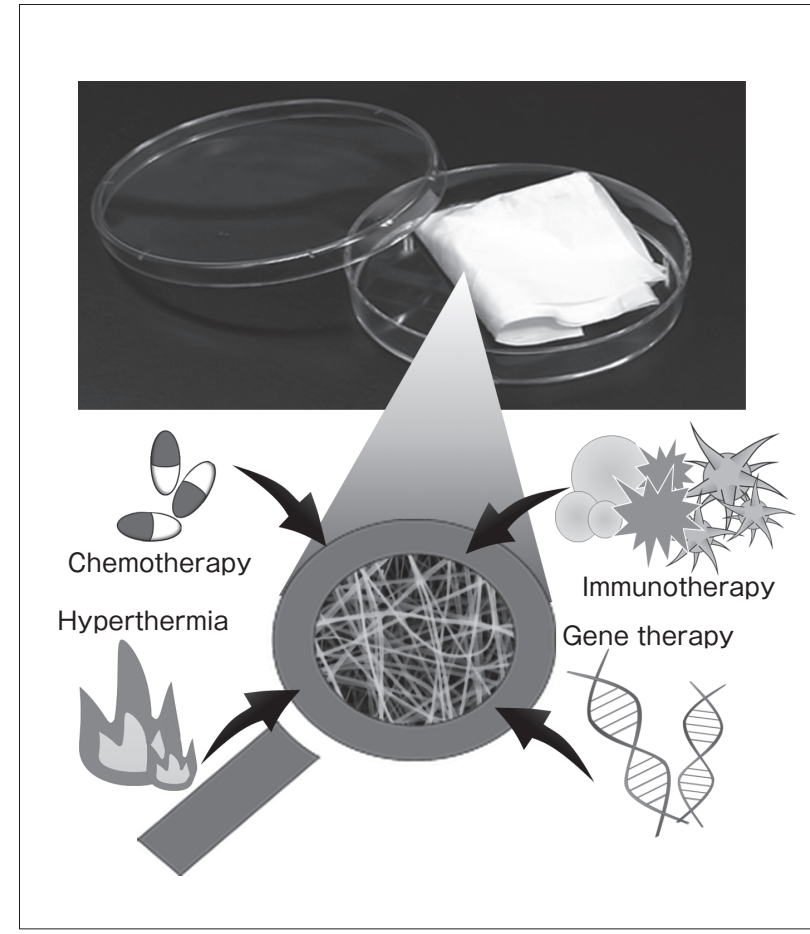

図2＼cjkstart電界紡糸法(エレクトロスピニング法)で作製したナノファイバー メッシュの写真

薬剤の種類によらず多種多様な薬剤を内包可能な点が最大の魅力。

われている。その1つが、薬剤の種類や大きさによ らず、何でも糸の中に練り込むことが可能な点があ げられる(図2)。ミセルやナノ粒子の場合、中に入 れる薬剤が疎水性の抗がん剤なのか microRNA な
のかによって材料設計をしなければならないが、電 界紡糸法に関しては薬剤の物性はほぼ問わず内包で き、内包率も理論上はほぼ100％となる。本稿では、 ナノファイバーメッシュをその機能ごとに分類し、 それぞれの DDS基材としての可能性について議論 する。その1つが、薬剤を長期徐放出可能なメッシュ である。2つ目が、刺激応答性のスマートポリマー を用いたメッシュで、薬剤の ON-OFF放出を実現 する。さらにこれらに発熱体を含有することで温熱・ 化学療法の併用が可能となる。

\section{2. 皮膚がん}

貼るがん治療の最初の例として、最もメッシュが 適応しやすい皮虐がんに注目した。皮膚がんは、オー ストラリアやニュージーランドをはじめとする多く の国で最も罹患率が高いがんである。外科的な切除 も行われるが、放射線療法や光線力学療法、凍結療 法に加え、抗腫瘍効果を発揮するクリームが一緒に 用いられることがある。イミキモドクリームは、イ ミダゾリン系化合物で、抗ウイルス、抗腫瘍効果を 有する免疫調節外用剤である。治療期間中は、数回 にわたり治療部位にクリームを塗布する必要がある が、背中など治療部位によっては塗布が困難である 
こと、皮膚の低い薬物透過性などに加え、副作用の 発生率も高く、極まれに重篤な障害が発生すること もある。さらに、長期的治療が必要な場合、塗布す るクリーム量が増えるため、副作用が深刻となり治 療の休止が必要なケースもある。これらの問題点を 解決するため、筆者らはクリームの主成分であるイ ミキモドをナノファイバーに内包させたメッシュ状 の徐放用生体材料の開発を行っている(図3 a $)^{2,3)}$ 。 ナノファイバーの原料として用いたポリーと-カプロ ラクトン (PCL) は、アメリカの FDA で臨床応用が 認可されている代表的な生分解性高分子である。イ ミキモドおよび PCL を電界紡糸させることで、イ ミキモド含有ナノファイバーを作製した。走査型電 子顕微鏡 $(\mathrm{SEM})$ 付属のエネルギー分散 $\mathrm{X}$ 線分光法 (EDX) を用いることで、ナノファイバーに内包さ せたイミキモドが、メッシュ全体に一様に分散し ていることを明らかとした。一方、広角X線回折
(XRD) 測定からは、イミキモド結晶由来のピーク は検出されなかった。以上の EDX およびXRDの 結果より、イミキモドは結晶化を起こすことなく均 一にナノファイバーに内包されていることが明らか となった。すなわち、電界紡糸によりイミキモドを ナノファイバー内に担持させることで、放出を妨げ る原因の1つである薬物結晶化が抑制できた。実際 に薬物放出を行ったところ、数日間にわたる放出が 観察された。現在までに約1力月にわたる徐放も確 認されている。今後ナノファイバー径やメッシュの 厚さ、イミキモド内包量や結晶性などの種々のパラ メーターを制御することで、皮膚がん治療に最適な 徐放能を有するナノファイバーメッシュの創出が可 能となる。 (a)

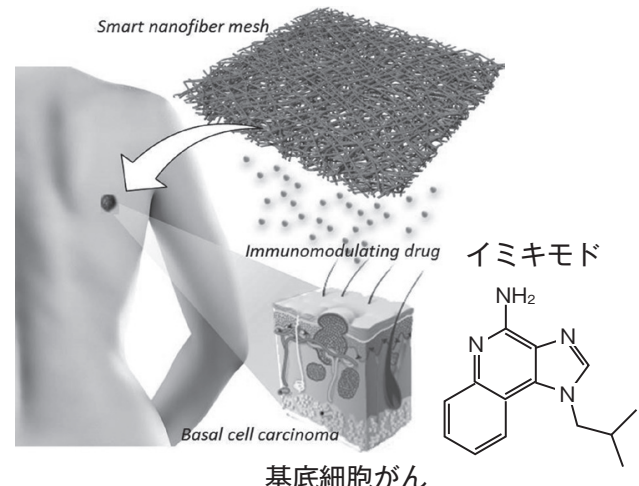

(c)

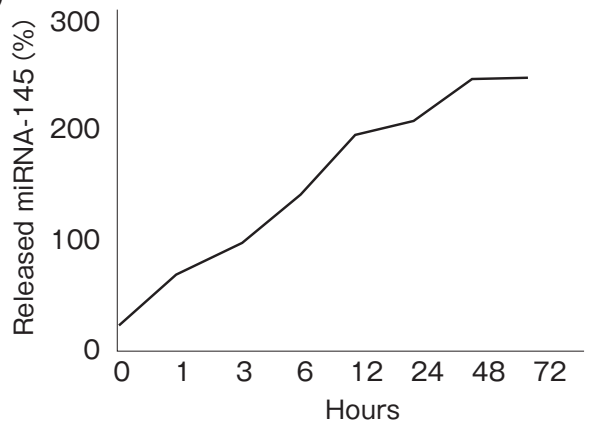

(b)

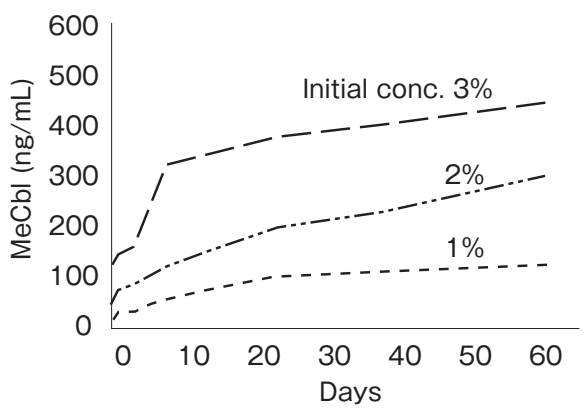

(d)

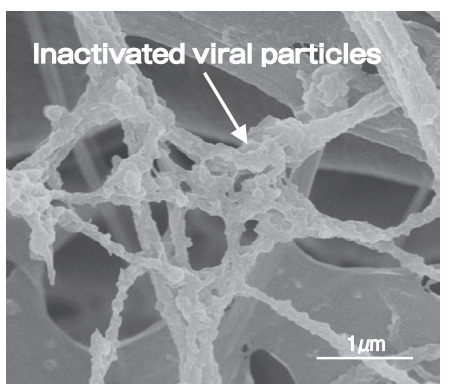

図3ＰCLナノファイバーメッシュを用いた局所DDS の例

(a) 免疫調節薬のイミキモドを内包した皮膚がん治療用ナノファイバーメッシュ。(b) 末梢神経保護用ナノファイバーメッシュからのビタミン剂の放出挙 動。(c)ナノファイバーメッシュからの microRNA の徐放。(d) 不活性化ウイルスをコーティングしたナノファイバーの SEM写真。 


\section{3. 末梢神経損傷}

同様のストラテジーが末梢神経損傷治療にも適応 できる。外傷などで末梢神経が損傷されると、運動 麻瘏や感覚麻疩および自律神経の障害などが起き る。この末梢神経障害の罹患率は加齢とともに増加 するため、超高齢社会を迎えるわが国においては社 会的な問題となっている。末梢神経損傷に対する治 療としては、切断部を直接縫合する方法や、体の他 の場所の神経を採取して移植する方法が一般的であ るが、近年では再生効果を支援するデバイスとして、 人工神経の開発も進んでいる。しかし現在使われて いる人工神経は、損傷部を単に橋わたしするだけで あり、神経軸索の再生速度を促進する効果は有して おらず、さらに不連続性神経損傷に対してのみ使用 されているため、多くの患者に使用することができ ないのが現状であった。こうした背景のもと筆者ら は、損傷した末梢神経に直接巻いて神経を保護し、 機能を回復できる PCLナノファイバーメッシュを 開発した。このシートは、神経を保護して再生を促 す機能に加え、神経系を正常に機能させるために重 要なビタミン $\mathrm{B}_{12}$ の1種メチルコバラミン $(\mathrm{MeCbl})$ を含有しており、生体内で適量ずつ経時的に放出さ れる仕組みとなっている(図3 b)。実際にこのメッ シュを坐骨神経損傷ラットに移植したところ、術後 6 週間で神経の軸索が再生され、運動機能と感覚機 能の回復が確認された は、手根管開放術、神経縫合術、神経交差縫合術、 神経剥離術、神経移行術、神経移植術など多くの症 例に対して使用可能であり、さらに形状記憶性兮を もたせることでさまざまな組織にもフィット可能な ため、今後さまざまな外科手術との併用に期待がも てる。

\section{4. 肝臓がん}

冒頭でも述べたとおり、ナノファイバーメッシュ を用いる最大の利点の1つに、内包可能な薬剤の多 様性があげられる。本項では microRNA (miRNA) 担持ナノファイバーメッシュについて紹介する。が んの発現は、遺伝子異常やがん抑制遺伝子の不活化
が関与している。肝蔵がんは、肺がんや子宮頸がん と並び、主要な発生要因が明らかになっているがん の1つであり、その要因は肝炎ウイルスの持続感染 により、炎症と再生が繰り返されて生じた遺伝子の 突然変異である。miRNA は mRNA と結合して遺 伝情報伝達を阻害する微小な核酸分子であり、その 遺伝情報の制御作用は、当初は線虫独特の現象と考 えられていた。しかしその後、細胞内での miRNA の作用異常が、結果として疾患の発症へとつながる ことが明らかとなった。実際に、がんを中心に数多 くの病気で miRNA を標的とした疾患治療の戦略が 現実化してきた。筆者らは、肝細胞がんの増殖・転 移を阻害することが報告されている miRNA-145に 着目した。miRNA-145の活性は不安定なため、ま ずはナノ粒子に miRNA-145を内包し、そのナノ粒 子を PCL ナノファイバーに固定化する方法を用い た。ナノ粒子は数日間の徐放効果がみられ、肝がん 細胞の増殖抑制効果を得られた $(\text { 図3 c })^{6)}$ 。この事 実は、ナノファイバーが遺伝子治療用の徐放担体と しても有用であることを示しており、遺伝子的アプ ローチによるがん細胞の殺傷から浸潤・転移抑制、 さらには正常細胞に戻す治療など、今後、さらなる 画期的な治療法開発が期待される。

\section{5. 悪性中皮腫}

さらに筆者らは、不活性化ウイルスを担持したナ ノファイバーの作製にも成功している。アスベスト 暴露が原因と考えられる悪性中皮腫は、20年以上 の潜伏期間を経て発症するため、アスベストの使用 が禁止されている現在であっても患者数は増加傾向 にある。中皮腫は胸膜、心膜、腹膜に発生するが、 やがて膜全体に拡大していくものが多い。治療法は 手術で膜の全切除または部分切除に加え、化学療法 や放射線療法も行われる。発見時にがんが膜全体に 広がっている場合が多く、進行ステージにより広範 囲での切除が必要となり、放射線療法などに対する 感受性もあまり強くはない。このような観点から、 免疫原性に基づいた免疫療法が注目されているが、 特異抗原やヒト白血球抗原関連分子の損失により、 期待しているほどの効果が得られていない。しかし 
ながら、近年、HVJ-E (Hemagglutinating virus of Japan envelope : 不活性化センダイウイルスエンベ ロープ)が、抗腫瘍免疫の増強やがん細胞死を誘導 することが明らかとなり、これを使用したがん治 療が注目されている7)。HVJは高い膜融合能をもつ ウイルスで、その内部に約 $15 \mathrm{kB}$ の RNA ゲノムを 含んでいる。HVJ-Eは、UV照射によりゲノムを 破壊させ複製能をなくすことで不活性化されてお り、核酸、抗体、抗がん剂などに対するエンベロー プベクターとしても注目を集めている。さらに近 年、HVJ-E自身が腫瘍細胞に対してアポトーシス を誘導することが報告された。HVJ-Eを使用した 治療への応用は、前立腺がんなどですでに臨床応用 が始まっており、抗がん活性を有する新しい材料と して期待されている。そこで筆者らは、ナノファイ バーメッシュにHVJ-E を吸着させ、標的部位に移 植した後に HVJ-E を放出可能な材料開発を行った $(\text { 図3 d })^{8)}$ 。非常に壊れやすいエンベロープを有する HVJ-E をPCL ナノファイバー表面に固定化するた めに、LBL(Layer-by-layer : 交互積層)法によるナ ノファイバー表面の機能化を施した。LBL法は、互 いに相互作用する高分子溶液に基板を交互に浸漬さ せるプロセスにより、基板表面に薄膜を形成させる 手法である ${ }^{9)}$ 。実際には、正に帯電した高分子溶液 と負に帯電した高分子溶液を交互にナノファイバー に浸漬させ、静電相互作用を駆動力とした高分子電 解質多層膜の形成を行った。HVJ-E表面は負に帯 電しているため、最外層に正電荷高分子層を有する 高分子電解質多層膜をナノファイバー表面上に形成 させることで、静電的吸着により HVJ-Eをナノファ イバー表面に固定化可能であった。ナノファイバー 表面からの HVJ-E放出は、8時間までの比較的初 期において急速であり、その後およそ72時間にわ たり HVJ-Eの放出が確認された。HVJ-E吸着ナノ ファイバーの抗がん活性を検討した結果、1日目か らがん細胞の殺傷効果が確認され、3日後でもがん 細胞の増殖が認められなかった。今後さらに、プ ラスミド DNA、ペプチド、抗体を封入した HVJ-E を吸着したナノファイバーの作製、ナノファイバー 内に磁性ナノ粒子や抗がん剤を内包させた HVJ-E 吸着ナノファイバーの開発等により、さまざまな応
用展開が期待できると考えられる。

\section{6. 肺がん}

最後に紹介する例は、ナノファイバーに発熱体を 内包させた温熱・化学療法用ナノファイバーメッ シュである。温熱療法とは、がん細胞が正常細胞と 比べ熱に弱いという性質を利用したがん治療法であ るが、副作用が少ないことや、他の治療法との併用 効果が高いことが数多く報告されている。例えば、 放射線に対して耐性をもつ細胞は一般的に熱感受性 が強いために、温熱と放射線の併用により相補的な 効果が得られる。また、化学療法との併用は、がん 組織中に扔ける薬物滞留性および吸収性を向上させ その効果を増強させる。しかしながら、臨床的には 異なる複数の治療法と温熱療法との併用を同時に行 うことは困難である。そこで筆者らは、肺がん治療 のための video-assisted thoracic surgery との併用 を目指し、化学療法と温熱療法を同時に行うナノ ファイバーメッシュの開発を行った $(\text { 図 } 4 a)^{10)}$ 。ま ず、ナノファイバーに担持させる発熱体として磁性 ナノ粒子 $\left(\mathrm{Fe}_{3} \mathrm{O}_{4} / \gamma-\mathrm{Fe}_{2} \mathrm{O}_{3}\right)$ に着目した。磁性ナノ 粒子は、交流磁場中においてヒステリシス損により 発熱する。生体内において発熱挙動を時空間的かつ 精密に制御することは困難であるが、ナノファイ バー内に磁性ナノ粒子を完全に内包することで、ナ ノファイバー周辺領域のみでの発熱を誘導可能とな る(図4 b)。さらに磁性ナノ粒子の内包量や照射す る磁場強度などにより、発熱挙動の精密制御も可能 である。電界紡糸法によりナノファイバー中に磁性 ナノ粒子と抗がん剤を同時に内包することは比較的 容易である。この系では磁性ナノ粒子の発熱と抗が ん剂放出による温熱・化学療法の達成が期待される が、さらに薬物放出の ON-OFF 制御能の付与を試 みた。この方法が実現すれば、所定時間に所定量の 薬物がナノファイバーを配置した局所で投与可能と なるため、現行の過剩な投薬に伴う副作用の軽減が 期待できる。これを達成するため、温度变化に対し て親水性と踈水性を可逆的に変化させる温度応答 性高分子、ポリ（N-イソプロピルアクリルアミド） (PNIPAAm)に着目した ${ }^{11)}$ 。PNIPAAm から構成さ 
れるナノファイバー内に内包された抗がん剤である パクリタキセルは、温度上昇によりナノファイバー 内から圧搾される形で放出される。これにより、交 流磁場照射をトリガーとして、内包した磁性ナノ粒 子が発熱し、上昇した温度による PNIPAAmナノ ファイバーの体積減少を誘発させ、内包薬物を圧搾 放出させるという一連の流れで、薬物放出が可能と
なる ${ }^{12)}$ 。肺腺がん細胞をモデル細胞として用いて材 料の抗がん活性を検討した結果、磁性ナノ粒子/抗 がん剂内包ナノファイバーはそれぞれを単独で内包 したナノファイバーと比較して、高い殺細胞効果を 示した(図4c)。結果として、ナノファイバーを用 いた温熱・化学療法の同時制御は、薬物単体および 温熱単体の治療よりはるかに高い相乗的抗がん活性

(a)

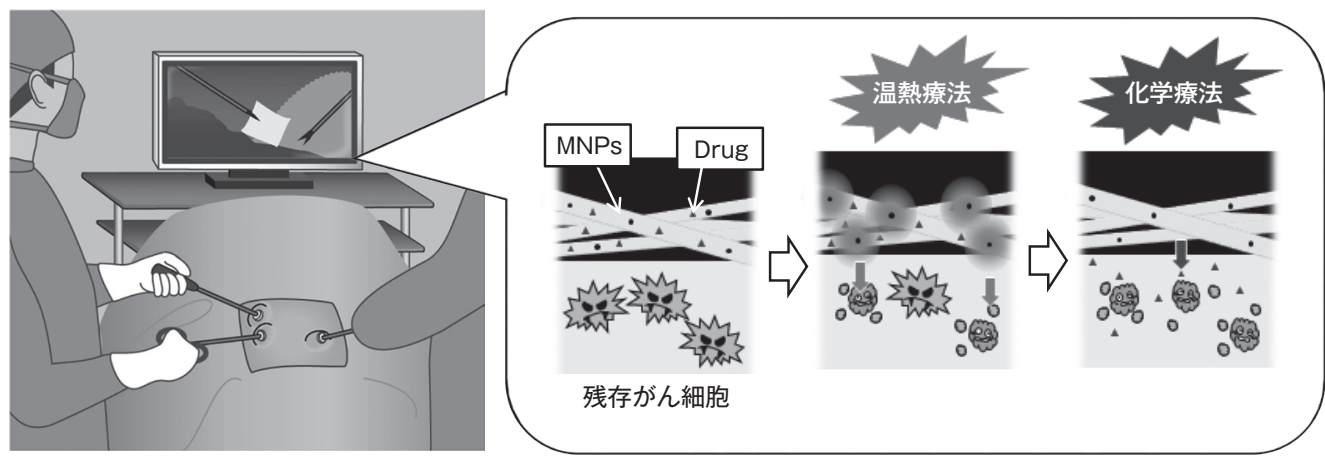

(b)

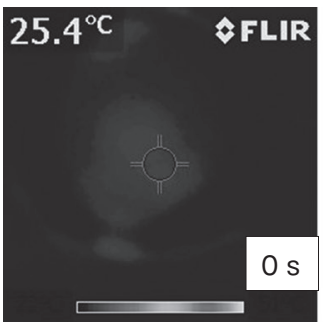

20 Temp. $\left({ }^{\circ} \mathrm{C}\right) 50$

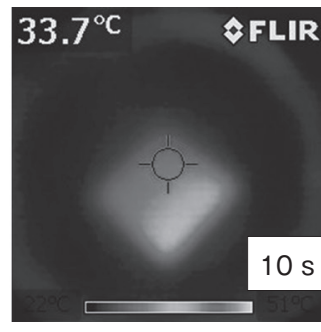

20 Temp. ( $\left.{ }^{\circ} \mathrm{C}\right) 50$

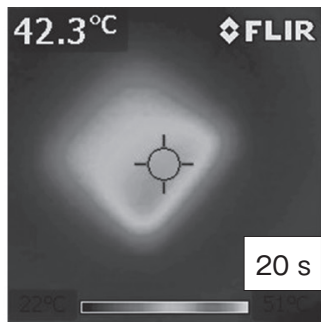

20 Temp. ( $\left(^{\circ} \mathrm{C}\right) 50$

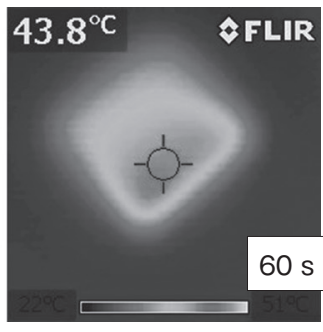

20 Temp. $\left({ }^{\circ} \mathrm{C}\right) 50$

(c)

肺腺がん細胞 ナノファイバーメッシュ
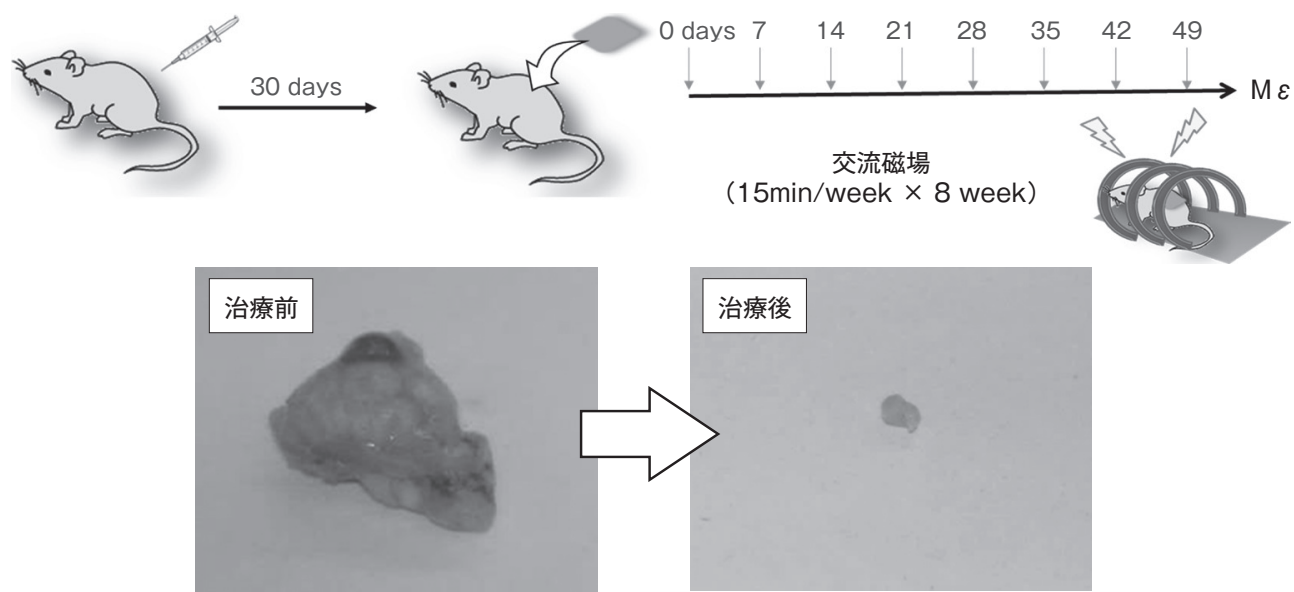

図4 ナノファイバーメッシュを用いたがんの温熱・化学療法

(a)ナノファイバーメッシュを用いたがんの温熱・化学療法の概念図。(b)磁性ナノ粒子(MNPs)内包ナノファイバーの交流磁場中での発熱挙動。(c)担が んマウスにナノファイバーメッシュを移植後、週に1回15分間交流時場を照射。この治療を 2 カ継続後、がんの縮小効果を確認。 
を発現できることが明らかとなった ${ }^{13)}$ 。さらに、ナ ノファイバー局所での温熱・化学療法であるため、 副作用の問題に効果的であることが期待される。

\section{7. おわりに}

本稿において紹介してきた局所埋め込み型ナノ ファイバーメッシュは、DDSキャリアとして魅力 的な材料であることはもちろんのこと、温熱療法と の併用や免疫活性化物質との組み合わせなど、今後 の応用次第によっては今までにない画期的な材料の 開発が可能であると考えられる。さらに近年、体内 の代謝リズム(体内時計)を利用した時間治療が注 目を集めている(図5) ${ }^{14)}$ 。スマートポリマーを用い た薬物の ON-OFF 制御はまさにこうしたニーズに マッチする。また、わが国の医療費に占める薬剤比

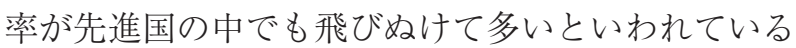
背景から、既知薬を別の疾患治療薬として応用する ドラッグリポジショニングが製薬企業では積極的に 取り入れられている。本稿で紹介したような材料を うまく用いることで、既知薬の効果を最大限に発揮 するマテリアルによるドラッグリポジショニングに

\section{文献}

1) Edited by N. D. Yilmaz, Smart Textiles: Wearable Nanotechnology, Wiley (2018)

2) R. Garrett, et al., Fibers, 3, 478-490 (2015)

3) W. Lin, et al., Polymers, 10,231 (2018)

4) K. Suzuki, et al., Acta Biomaterialia, 53, 250-259 (2017)

5) E. Niiyama, et al., Fibers, 7, 20 (2019)

6) H.-L. Che, et al., J. Nanoscience and Nanotechnology, 15, 7971-7975 (2015)

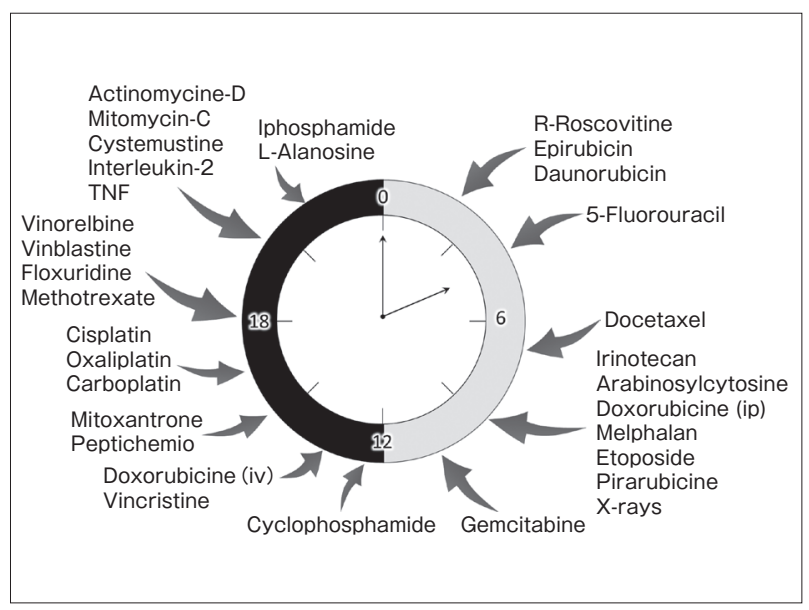

図5 時間治療の概念図

抗がん剂の種類によって体内時計によって最大限に効果が発揮できる夕 イミングが異なる。

も今後期待がもてる。

\section{謝辞}

本稿執筆拉よび研究遂行にあたり多大なるご助言をいた だいた Allan S. Hoffman名誉教授(Univ. Washington) 㧍よ び Patrick S. Stayton教授(Univ. Washington)にこの場をか りて感謝申しあげます。

7) M. Kurooka, et al., Cancer Res., 67, 227-236 (2007)

8) T. Okada, et al., Materials, 9, 12 (2016)

9) T. Okada, et al., Langmuir, 29, 7384-7392 (2013)

10) E. Niiyama, et al., Advanced Healthcare Materials, (2019) in press.

11) Y.-J. Kim, et al., Angewandte Chemie International Edition, 51,10537-10541 (2012)

12) Y.-J. Kim, et al., Adv. Func. Mater., 23, 5753-5761 (2013)

13) E. Niiyama, et al., Polymers, 10,1018 (2018)

14) F. Lévi, Cancer Causes Control, 17,611-621 (2006) 